\title{
PENERAPAN METODE CASE BASED REASONING (CBR) UNTUK SISTEM PENENTUAN STATUS GUNUNG GAMALAMA
}

\author{
Ariyandi S. Soroto ${ }^{1}$, Achmad Fuad ${ }^{2}$, Salkin Lutfi ${ }^{3}$ \\ Program Studi Teknik Informatika, Fakultas Teknik, Universitas Khairun \\ Jl. Jati Metro, Kota Ternate Selatan \\ E-Mail : Ariyandi.sdabel@gmail.com ${ }^{1}, \underline{A d}$ _4ss@yahoo.com ${ }^{2}$, Salkin.lutfi@gmail.com ${ }^{3}$
}

\begin{abstract}
The geographical position of Indonesia is at the meeting of two plates, namely Asia and Australia, this causes many volcanoes. In addition, the mountains in Indonesia are dominated by active volcanoes and potentially erupt at any time. One of the mountains that has a history of frequent eruption is Mount Gamalama, which is one of the active volcanoes in Ternate City. These conditions require residents who are around Gamalama mountain to respond to the disaster caused by the eruption of Mount Gamalama. This study resulted in an Early Warning System of Gamalama Mountain status. The training data used is taken from the Office of Geological Agency of Volcanology and Mount Gamalama Disaster Mitigation which is classified into three statuses namely normal and alert. Method Case Based Reasoning is a problem-solving approach by emphasizing the role of prior experience. Based on test result with 3 experiment scenarios obtained an average accuracy of $80 \%$ and the highest similarity percentage of $99.86 \%$. Thus it can be said that the system of determining the status of gamalama mountain can be applied by Case Based Reasoning method.
\end{abstract}

Keywords: Case Based Reasoning, Gamalama, Geology Agency.

Abstrak - Letak geografis Indonesia berada di pertemuan dua lempeng yaitu Asia dan Australia, hal ini menyebabkan banyak terdapat gunung berapi. Selain itu pegunungan di Indonesia didominasi oleh gunung yang aktif dan berpotensi meletus sewaktu-waktu. Salah satu gunung yang memiliki riwayat letusan yang cukup sering yaitu gunung Gamalama, yang merupakan salah satu gunung aktif yang ada di Kota Ternate. Kondisi tersebut mengharuskan warga yang berada disekitar gunung Gamalama untuk tanggap akan bencana yang diakibatkan oleh letusan gunung Gamalama. Penelitian ini menghasilkan suatu Sistem Peringatan Dini status gunung gamalama. Data latih yang digunakan diambil dari Kantor Badan Geologi Pusat Vulkanologi dan Mitigasi Bencana Gunung Gamalama yang diklasifikasikan dalam tiga status yaitu normal, siaga, dan waspada. Metode Case Based Reasoning merupakan sebuah pendekatan penyelesaian masalah dengan menekankan peran pengalaman sebelumnya. Berdasarkan hasil pengujian dengan 3 skenario percobaan didapat akurasi rata-rata sebesar $80 \%$ dan persentasi kemiripan tertinggi sebesar $\mathbf{9 9 , 8 6 \%}$. Dengan demikian dapat dikatakan bahwa sistem penentuan status gunung gamalama dapat diterapkan dengan metode Case Based Reasoning.

Kata Kunci : Case Based Reasoning, Gamalama, Badan Geologi.

\section{PENDAHULUAN}

Indonesia memiliki sejarah kejadian bencana alam yang cukup banyak, diantaranya adalah tsunami, gempa bumi, kekeringan, banjir, letusan gunung api dan sebagainya. Salah satu penyebab banyaknya potensi kejadian bencana alam di Indonesia adalah letak Indonesia yang berada di pertemuan lempenglempeng Eurasia, Indo-Australia dan Pasifik. Pertemuan lempeng dalam jangka panjang akan menghimpun energi yang suatu waktu akan lepas dan dapat menghasilkan bencana. Pertemuan antar lempeng juga menyebabkan Indonesia berada di jalur "The Ring of Fire" (Cincin Api) yang merupakan jalur rangkaian gunung api aktif di dunia. Hal tersebut dibuktikan dengan banyaknya jumlah gunung api di Indonesia yang berjumlah sekitar 129 gunung dengan beberapa diantaranya memiliki sejarah letusan yang hebat [1].
Letusan gunung api merupakan peristiwa keluarnya magma dari dalam perut bumi melalui puncak gunung api dengan kekuatan besar sehingga mengeluarkan lava pijar dan batuan/debu vulkanik [1]. gunung yang memiliki riwayat letusan yang cukup sering adalah gunung Gamalama, gunung Gamalama merupakan salah satu gunung api aktif yang berada di Provinsi Maluku Utara, secara administratif terletak di Kota Ternate dengan ketinggian 1715 meter di atas permukaan laut. Gunung Gamalama terletak di atas jalur penunjaman (subduction zone) yang miring ke timur dengan sudut yang kecil, hal tersebut menyebabkan gunung Gamalama ini termasuk salah satu gunung yang dinilai cukup berbahaya [2].

Pada saat penentuan status gunung berapi, hal yang harus diperhatikan adalah karakteristik dan tingkat aktifitas gunung berapi tersebut. Seperti penentuan status gunung Gamalama dimana hal yang paling diperhatikan adalah berapa banyak gempa tektonik dan gempa vulkanik, ketika gempa vulkanik 
sudah lebih dari 5 kali maka status gunung Gamalama akan dinaikan. ada beberapa kekurangan pada kantor pemantauan gunung Gamalama yakni status gunung hanya dikeluarkan oleh tim pemantau sedangkan tim pemantau yang aktif tersisa 2 orang, keterlambatan mengeluarkan status dapat terjadi jika tim pemantau sedang ada kegiatan maupun berhalangan datang di kantor. Selain itu tim pemantau hanya bisa mengeluarkan status kemudian di sampaikan ke Pemda, dari Pemdalah yang akan menyampaikan ke masyarakat. Penelitian terkait penentuan status gunung dengan menggunakan metode CBR pernah dibuat oleh [7] dimana data-data yang diterapkan yaitu seluruh aktivitas gunung yang ada di Indonesia.

Berdasarkan masalah tersebut maka peneliti ingin membangun suatu sistem yang dapat mempermudah dalam mengklasifikasi status gunung Gamalama dengan menggunakan metode Case Based Reasoning $(C B R)$, dimana Inti dari proses $C B R$ adalah menghitung nilai similarity atau kesamaan antara kasus lama dengan kasus baru untuk melihat akurasi yang didapat. Pada pencarian kesamaan dengan mengacu pada proses retrieve, bagaimana pakar harus memperbaiki permasalahan dan mencari bobot tertinggi.

\section{TINJAUAN PUSTAKA}

\section{A. Metode Case Based Reasoning (CBR)}

Menurut Aamodt dan Plaza (1994) Case-Based Reasoning adalah suatu pendekatan untuk menyelesaikan suatu permasalahan (problem solving) berdasarkan solusi dari permasalahan sebelumnya. Case-Based Reasoning ini merupakan suatu paradigma pemecahan masalah yang banyak mendapat pengakuan yang pada dasarnya berbeda dari pendekatan utama Artificial Intelligent lainnya. Suatu masalah baru dipecahkan dengan menemukan kasus yang serupa di masa lampau, dan menggunakannya kembali pada situasi masalah yang baru.

Perbedaan lain dari Case-Based Reasoning yang tidak kalah penting adalah Case-Based Reasoning juga merupakan suatu pendekatan ke arah incremental yaitu pembelajaran yang terus-menerus.

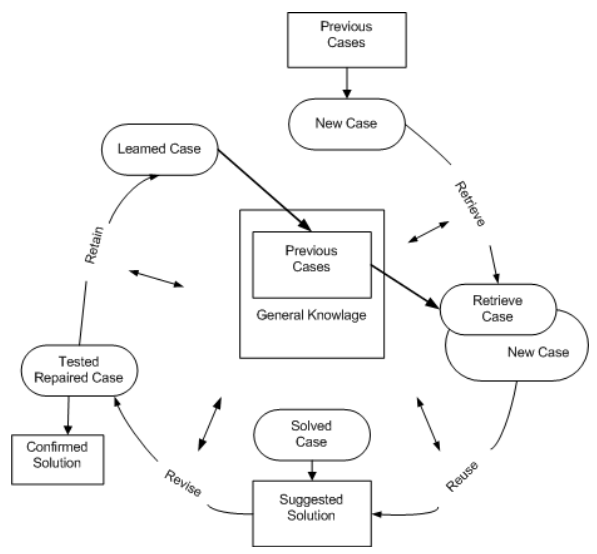

Gambar 1. Tahapan Proses Metode CBR
Dari gambar 1 bisa di jelaskan dalam Case-Based Reasoning ada empat tahapan yang meliputi :

\section{Retrieve}

Mendapatkan/memperoleh kembali kasus yang paling menyerupai/relevan (similar) dengan kasus yang baru. Tahap retrieval ini dimulai dengan menggambarkan/ menguraikan sebagian masalah, dan diakhiri jika ditemukannya kecocokan terhadap masalah sebelumnya yang tingkat kecocokannya paling tinggi. Bagian ini mengacu pada segi identifikasi, kecocokan awal, pencarian dan pemilihan serta eksekusi.

2. Reuse

Memodelkan/menggunakan kembali pengetahuan dan informasi kasus lama berdasarkan bobot kemiripan yang paling relevan ke dalam kasus yang baru, sehingga menghasilkan usulan solusi dimana mungkin diperlukan suatu adaptasi dengan masalah yang baru tersebut.

\section{Revise}

Meninjau kembali solusi yang diusulkan kemudian mengetesnya pada kasus nyata (simulasi) dan jika diperlukan memperbaiki solusi tersebut agar cocok dengan kasus yang baru.

\section{Retain}

Mengintegrasikan/menyimpan kasus baru yang telah berhasil mendapatkan solusi agar dapat digunakan oleh kasus-kasus selanjutnya yang mirip dengan kasus tersebut. Tetapi Jika solusi baru tersebut gagal, maka menjelaskan kegagalannya, memperbaiki solusi yang digunakan, dan mengujinya lagi.

Rumus yang digunakan dalam mencari kemiripan [3] [4] adalah sebagai berikut :

$$
f(s, t)=1-\left|\frac{T-s}{N}\right|
$$

Keterangan :

$\mathrm{T}:$ Kasus baru

$S$ : Kasus yang ada dalam penyimpanan

$\mathrm{N}$ : Nilai tertinggi dari suatu himpunan

\section{B. Akurasi Data}

Akurasi merupakan metode pengujian berdasarkan tingkat kedekatan antara nilai prediksi dengan nilai aktual [5]. Dengan mengetahui jumlah data yang diklasifikasikan secara benar maka dapat diketahui akurasi hasil prediksi. Persamaan akurasi seperti pada persamaan berikut.

$$
\text { Akwrasi }=\frac{\text { Diagnasis Benar }}{\text { Diagnasis Benar + Diagnasis Salah }} \times 100 \%
$$

\section{Gunung Berapi}

sGunung api adalah tempat keluarnya magma yang mempunyai kenampakan di permukaan bumi sebagai suatu bagian puncak gunung berbentuk kerucut, deretan kerucut atau hanya berupa lubang letusan dan atau kawah. Prosedur Tetap Tingkat Kegiatan Gunung Api terbagi menjadi 4 yaitu :

1. Aktif Normal (Level I). Kegiatan gunungapi berdasarkan pengamatan dari hasil visual, 
kegempaan dan gejala vulkanik lainnya tidak memperlihatkan adanya kelainan

2. Waspada (Level II). Terjadi peningkatan kegiatan berupa kelainan yang tampak secara visual atau hasil pemeriksaan kawah, kegempaan dan gejala vulkanik lainnya

3. Siaga (Level III). Peningkatan semakin nyata hasil pengamatan visual/pemeriksaan kawah, kegempaan dan metoda lain saling mendukung. Berdasarkan analisis, perubahan kegiatan cenderung diikuti letusan

4. Awas (Level IV). Menjelang letusan, letusan awal mulai terjadi berupa abu/asap. Berdasarkan analisis data, segera akan diikuti letusan utama [6].

\section{METODE PENELITIAN}

\section{A. Pengumpulan Data}

Pada data yang akan dijadikan kasus lama maupun data uji di ambil langsung pada Kantor Badan Geologi dan Pusat Vulkanologi Mitigasi Bencana Gunung
Gamalama Ternate. Data yang akan dijadikan data kasus lama dan data uji adalah data latusan Gunung Gamalama dari tahun 2011 - 2016. Salain pengambilan data langsung peneliti juga melakukan wawancara yang bertujuan untuk mengetahui bagaimana cara kantor vulkanologi mengeluarkan status gunung Gamalama dan apa karakteristik dari gunung Gamalama tersebut

\section{B. Perancangan Sistem}

Proses penelitian diawali dengan pengumpulan data latih yang biasa disebut dengan dataset status gunung Gamalama, selanjutkan ditentukan fitur-fitur yang dapat mempresentasikan karakteristik status gunung Gamalama. Tahapan selanjutnya adalah pemilihan model, bagaimana memodelkan fitur-fitur gunung Gamalama untuk menentukan kesamaan terdekat dengan menggunakan tahapan metode $C B R$. Pada proses selanjutnya yaitu membuat diagram UML, membuat algoritma atau pseudocode dan kemudian kita merancang tampilan interface-nya.

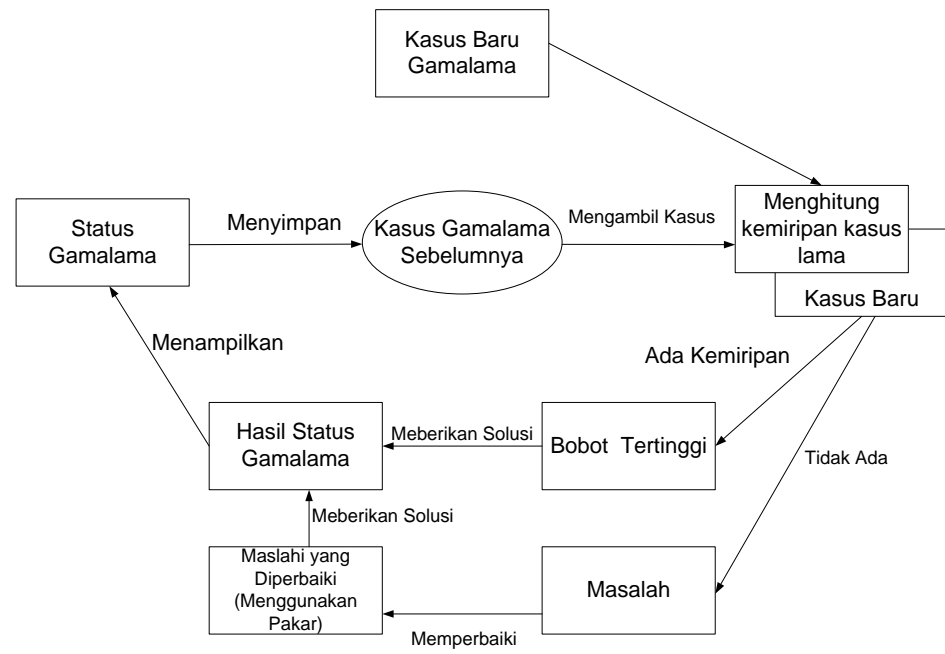

Gambar 2. Proses CBR Pada Kasus Gunung Gamalama

Pada metode Case Based Reasoning ada 4 tahapan proses yang dilakukan yaitu Retrieve, Reuse, Revise dan Retain. cara kerjanya berpedoman pada basis pengetahuan atau data kejadian yang terjadi pada gunung Gamalama, kemudian dihitung tingkat kemiripan dengan kasus baru yang terjadi. Berdasarkan tingkat kemiripan kasus inilah yang kemudian akan didapat rekomendasi status dari gunung Gamalama.

Tahapannya dimulai dari kasus baru dimasukan kemudian data pada kasus baru di cari kemiripan dengan kasus lama dengan cara mencari nilai similarity tertinggi, ketika nilai tertinggi ditemukan maka hasil dari status gunung kemudian ditampilkan dan ketika tidak mendapatkan bobot tertinggi maka akan diarahkan ke masalah dan akan diselesaikan oleh seorang pakar. Setelah itu status gunung kemudian ditampilkan dan pada tahap berikut merupakan tahap penyimpanan kasus baru yang dijadikan sebagai kasus lama.

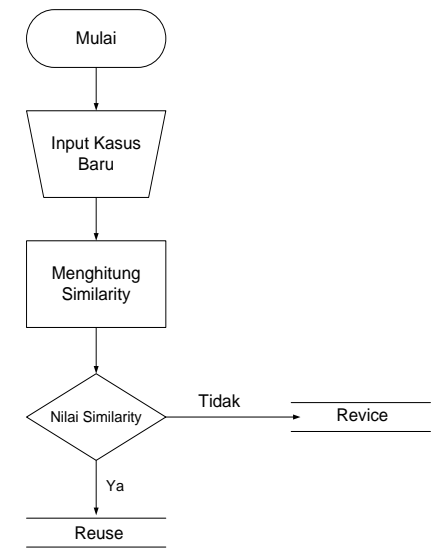

Gambar 3. Proses Retrieve

Pada proses ini bagaimana mencari kemiripan kasus baru dengan kasus lama (dataset) yang sudah di ambil tersebut. Pada awalnya dimasukan data baru dari gunung Gamalama, kemudian dari data baru tersebut dicari kemiripan tertinggi dengan dataset gunung Gamalama. 
Pada awal menggunakan aplikasi, seorang admin dihadapkan oleh tampilan utama, Admin diberikan hak untuk mengelola aplikasi. Untuk mengelola aplikasi, admin harus login dengan menggunakan username dan password yang sudah di daftarkan sebelumnya. Jika berhasil admin berhasil login maka admin diberikan hak akses sebagai berikut :

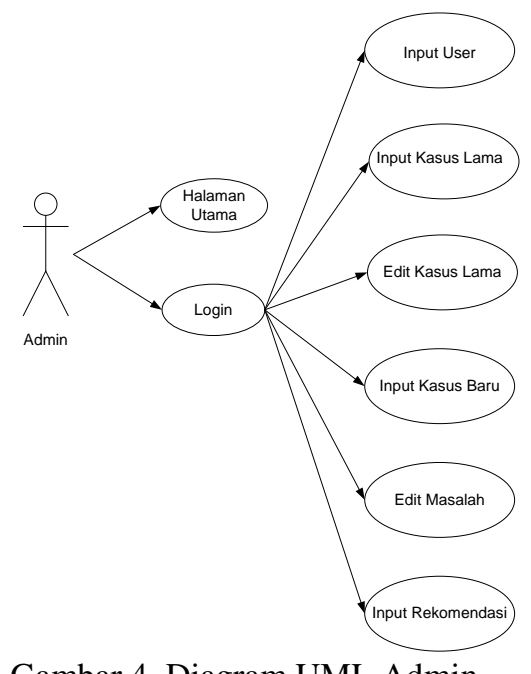

Gambar 4. Diagram UML Admin

\section{Algoritma atau Pseudocode}

Proses pencarian nilai kemiripan pada kasus baru sangat berpengaruh pada kasus lama yang ada, semakin akuratnya kasus lama dapat meningkatkan akurasi juga pada saat pencarian kasus baru. Tahapan pencarian nilai kemiripan pada kasus baru dan kasus lama dapat dilihat pada pseudocode berikut :

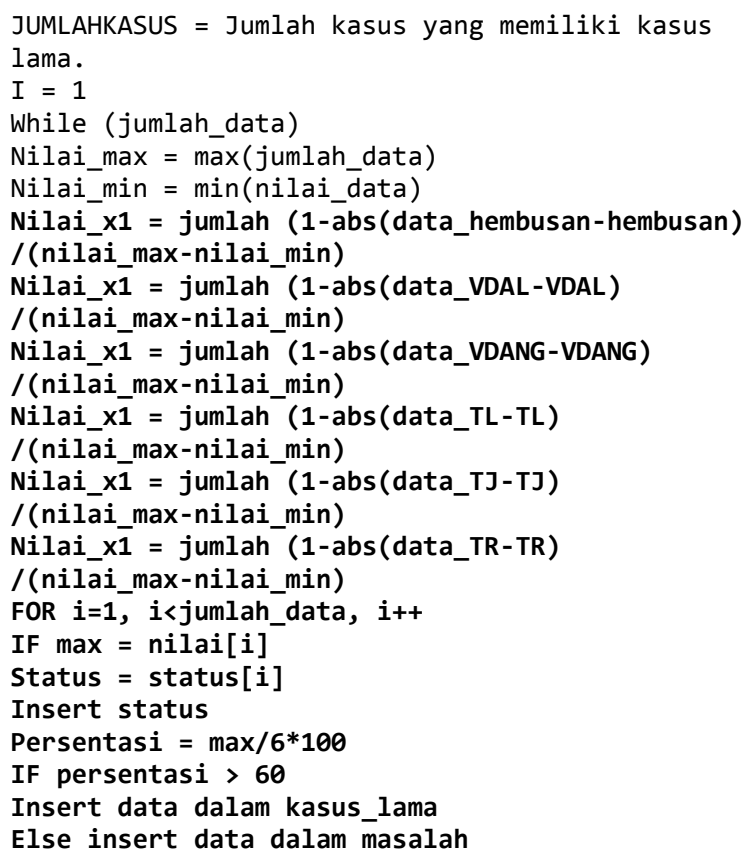

\section{HASIL DAN PEMBAHASAN}

A. Implementasi Basis Data
Pada aplikasi penentuan status gunung gamalama dengan menggunakan metode Case Based Reasoning terdapat 4 tabel yaitu tabel user, tabel kasus lama, tabel masalah dan tabel rekomendasi. Tabel user untuk menampung data user, tabel kasus lama untuk menampung data kasus terdahulu, table masalah untuk menampung data masalah dan tabel rekomendasi untuk menampung data rekomendasi dari status.

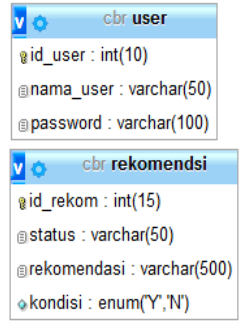

Gambar 5. Struktur Tabel Pada Basis Data

\section{B. Implementasi Interface}

Dalam aplikasi penentuan status gunung Gamalama dengan menggunakan metode Case Based Reasoning ini mengimplementasikan beberapa interface yang dimulai dari interfaces input sampai pada interfaces output. Salah satu Implementasi interfaces dapat dilihat sebagai berikut :

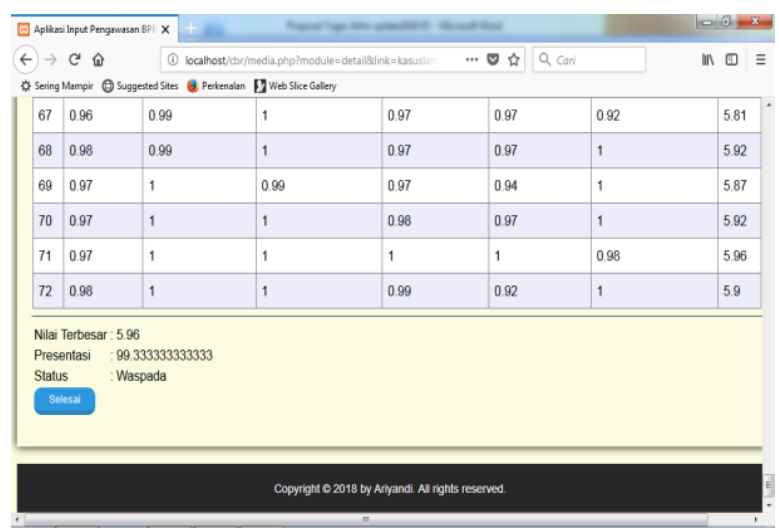

Gambar 6. Tampilan Hasil Perhitungan

\section{Pengujian Metode}

Simulasi yang dilakukan memiliki 3 tahap, tahap pertama simulasi dengan menggunakan 20 kasus lama dan 20 kasus sebagai data uji, simulasi kedua menggunakan 50 kasus lama dan 20 datan uji dan simulasi ketiga menggunakan 72 kasus lama dan 20 kasus baru sebagai uji coba.

Tabel 1. Data Uji

\begin{tabular}{|c|c|c|c|c|c|c|c|}
\hline Data & HMB & VD & VDL & TL & TJ & TR & Status \\
\hline 1 & 1 & 0 & 0 & 4 & 8 & 0 & Normal \\
\hline 2 & 3 & 0 & 0 & 2 & 10 & 0 & Normal \\
\hline 3 & 0 & 0 & 0 & 1 & 9 & 0 & Normal \\
\hline 4 & 1 & 1 & 0 & 2 & 11 & 0 & Normal \\
\hline 5 & 2 & 0 & 0 & 5 & 13 & 0 & Normal \\
\hline 6 & 10 & 3 & 1 & 5 & 24 & 1 & Siaga \\
\hline 7 & 5 & 6 & 139 & 2 & 7 & 0 & Siaga \\
\hline
\end{tabular}




\begin{tabular}{|c|c|c|c|c|c|c|c|}
8 & 79 & 0 & 0 & 1 & 3 & 2 & Siaga \\
\hline 9 & 69 & 4 & 1 & 0 & 16 & 11 & Siaga \\
\hline 10 & 51 & 1 & 0 & 0 & 4 & 1 & Siaga \\
\hline 11 & 64 & 0 & 2 & 31 & 3 & 1 & Siaga \\
\hline 12 & 61 & 1 & 0 & 2 & 5 & 2 & Siaga \\
\hline 13 & 8 & 0 & 0 & 5 & 8 & 0 & Waspada \\
\hline 14 & 4 & 0 & 0 & 3 & 11 & 0 & Waspada \\
\hline 15 & 92 & 9 & 7 & 3 & 15 & 1 & Waspada \\
\hline 16 & 15 & 5 & 0 & 1 & 3 & 0 & Waspada \\
\hline 17 & 54 & 1 & 0 & 1 & 12 & 0 & Waspada \\
\hline 18 & 47 & 0 & 0 & 0 & 7 & 0 & Waspada \\
\hline 19 & 38 & 4 & 0 & 2 & 14 & 0 & Waspada \\
\hline 20 & 24 & 0 & 0 & 1 & 14 & 0 & Waspada \\
\hline
\end{tabular}

Pada percobaan pertama dalam 92 data pada kasus gunung Gamalama peneliti mengambil 20 data sebagai data lama dan 20 data sebagai data uji, pada data lama peneliti mengambil 5 data berstatus normal, 7 data berstatus siaga dan 8 data berstatus waspada. perhitungan dari 20 kasus sebagai data lama dan 20 kasus sebagai data uji, peneliti mendapatkan hasil 16 data uji memiliki kemiripan dengan data lama sedangkan 4 dari data uji hasilnya berbeda. Pengujian ini juga menghasilkan persentasi kemiripan tertinggi dengan hasil mencapai 99,86\%.

Pada percobaan kedua peneliti melakukan simulasi dalam 92 data pada kasus gunung Gamalama peneliti mengambil 50 data sebagai data lama dan 20 data sebagai data uji, pada data lama peneliti mengambil 9 data berstatus normal, 19 data berstatus siaga dan 22 data berstatus waspada. lihat perhitungan dari 50 kasus sebagai data lama dan 20 kasus sebagai data uji, peneliti mendapatkan hasil 16 data uji memiliki kemiripan dengan data lama sedangkan 4 dari data uji hasilnya berbeda.

Pada percobaan kedua peneliti melakukan simulasi dalam 92 data pada kasus gunung Gamalama peneliti mengambil 72 data sebagai data lama dan 20 data sebagai data uji, pada data lama peneliti mengambil 14 data berstatus normal, 26 data berstatus siaga dan 32 data berstatus waspada. perhitungan dari 72 kasus sebagai data lama dan 20 kasus sebagai data uji, peneliti mendapatkan hasil 17 data uji memiliki kemiripan dengan data lama hanya saja pada data ke 5 memiliki dua nilai yang sama yaitu pada Normal dan Waspada, karena kasus yang ditemukan belum bisa diatasi maka sistem menentukan hasilnya berbeda sehingga hanya 16 data yang ditemukan mirip sedangkan 4 dari data uji hasilnya berbeda.

Tabel 2. Hasil Pengujian

\begin{tabular}{|c|c|c|c|c|}
\hline Data & Status & $\begin{array}{c}\text { Hasil } \\
\text { Uji 20 } \\
\text { kasus }\end{array}$ & $\begin{array}{c}\text { Hasil } \\
\text { Uji 50 } \\
\text { Kasus }\end{array}$ & $\begin{array}{c}\text { Hasil } \\
\text { Uji 72 } \\
\text { Kasus }\end{array}$ \\
\hline 1 & Normal & Normal & Normal & Normal \\
\hline 2 & Normal & Normal & Normal & Normal \\
\hline 3 & Normal & Normal & Normal & Normal \\
\hline 4 & Normal & Normal & Normal & Normal \\
\hline 5 & Normal & Normal & Normal & Waspada \\
\hline 6 & Siaga & Waspada & Waspada & Waspada \\
\hline 7 & Siaga & Normal & Waspada & Waspada \\
\hline 8 & Siaga & Siaga & Siaga & Siaga \\
\hline
\end{tabular}

\begin{tabular}{|c|c|c|c|c|}
9 & Siaga & Siaga & Siaga & Siaga \\
\hline 10 & Siaga & Siaga & Siaga & Siaga \\
\hline 11 & Siaga & Siaga & Siaga & Siaga \\
\hline 12 & Siaga & Siaga & Siaga & Siaga \\
\hline 13 & Waspada & Waspada & Waspada & Waspada \\
\hline 14 & Waspada & Normal & Normal & Waspada \\
\hline 15 & Waspada & Siaga & Siaga & Siaga \\
\hline 16 & Waspada & Waspada & Waspada & Waspada \\
\hline 17 & Waspada & Waspada & Waspada & Waspada \\
\hline 18 & Waspada & Waspada & Waspada & Waspada \\
\hline 19 & Waspada & Waspada & Waspada & Waspada \\
\hline 20 & Waspada & Waspada & Waspada & Waspada \\
\hline
\end{tabular}

Dari ketiga skenario tersebut menunjukan bahwa semakin banyak data lama yang digunakan, semakin besar nilai akurasi yang didapat. Hal ini ditunjukan dengan nilai akurasi yang didapat pada skenario ketiga dengan nilai akurasi sebesar $80 \%$ meskipun pada pengujiannya terdapat hasil yang sama. Data yang di dijadikan data lama juga sangat berpengaruh dengan hasil penentuan status. Grafik dari perhitungan dapat dilihat pada gambar berikut :

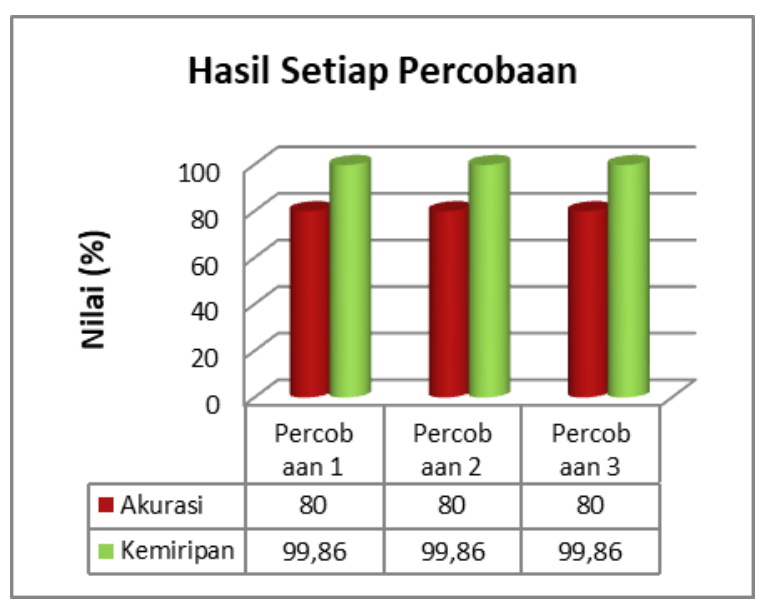

Gambar 7. Grafik Hasil Percobaan

\section{Pengujian Sistem}

Berdasarkan pengujian yang telah dilakukan yaitu pengujian sistem dengan metode Blackbox menunjukan bahwa Aplikasi penentuan status gunung Gamalama dengan menggunakan metode Case Based Reasoning terdiri dari dua level pengguna yaitu level admin yang harus melakukan login terlebih dahulu untuk masuk ke sistem dan level user biasa yang merupakan masyarakat yang ingin mengetahui status gunung Gamalama saat ini. Karena user biasa fungsinya hanya untuk mendapatkan informasi status gunung maka tidak perlu melakukan login.

Selain itu aplikasi penentuan status gunung Gamalama juga memiliki interfaces yang dibuat sesuai dengan perancangan yaitu terdiri halaman utama yang dapat di akses oleh semua level pengguna, pada tampilan halaman utama terdapat informasi status gunung yang kapan saja dapat dilihat oleh masyarakat dan tampilan menu login yang khusus di akses oleh admin. Jika admin berhasil login maka akan di tampilkan halaman admin yang terdiri dari menu Anggota untuk menyimpan data admin, menu Kasus Lama yang bertujuan untuk meng-input data-data kasus lama yang 
akan dipakai untuk direkomendasikan menjadi kasus baru, menu Kasus Baru bertujuan untuk menginput kasus baru yang akan dicocokkan pada kasus lama, menu Masalah yang brtujuan untuk menampilkan data-data dari kasus baru yang tidak memiliki kecocokan dengan data kasus lama sehingga perlu seorang pakar untuk memperbaiki masalah tersebut.

Ketika data baru di input-kan maka tampilan akan di arahkan pada proses perhitungan, dimana pada proses perhitungan terlihat data lama dari kasus gunung gamalama, proses hasil hitung kesamaan antara setiap gempa dan juga menampilkan nilai terbesar dan hasil dari status kasus baru. Kemudian ketika tombol selesai di klik maka tampilan akan diarahkan ke halaman kasus lama. Dengan demikian hasil analisis pengujian sistem menggunakan metode blackbox menunjukan bahwa input maupun output pada sistem sudah berjalan sesuai dengan perancangan sistem.

\section{KESIMPULAN}

1. Aplikasi penentuan status gunung Gamalama dengan menggunakan metode Case Based Reasoning dapat dibuat dengan bahasa pemrograman $P H P$, paket Xampp Control pada versi 3.2.2 (Apache dan MySQL) sebagai webserver, Notepad++ sebagai editor dan Firefox sebagai Web Browser.

2. Dari ketiga skenario yang dilakukan, yaitu skenario pertama dengan 20 data lama diuji ulang menunjukan akurasi sebesar $80 \%$ dan kemiripan tertinggi $99,86 \%$, skenario ke dua dengan 50 data lama diuji ulang menunjukan akurasi $80 \%$ dan kemiripan tertinggi dengan nilai $99,86 \%$, dan skenario ke tiga dengan 72 data lama diuji ulang mendapatkan nilai akurasi sebesar $80 \%$ walaupun pada perhitungannya data ke-5 memiliki hasil nilai yang sama dan kemiripan tertinggi sebesar $99,16 \%$.

3. Hasilnya menunjukan ketika data yang dijadikan sebagai data lama yang sedikit, nilai akurasi sistem akan kecil meskipun nilai similarity antara kasus lama dan kasus baru tinggi. Namun ketika ditambahnya data lama ke database, dapat meningkatkan nilai akurasi dari aplikasi ini. Itu dilihat dari skenario ke tiga yang memiliki nilai akurasi mencapai $80 \%$.

4. Hasil dari analisis pengujian sistem dengan menggunakan metode blackbox menunjukan bahwa implementasi interfaces dari proses input maupun proses output pada sistem penentuan status gunung Gamalama telah berjalan sesuai dengan perancangan sistem.

5. Aplikasi yang telah dibangun dengan menggunakan metode Case Based Reasoning mampu mengambil kasus lama dalam dataset yang sesuai untuk menyelesaikan kasus baru dengan tingkat akurasi rata-rata sebesar $80 \%$. Dengan demikian metode Case Based Reasoning dinilai dapat digunakan dalam penentuan status gunung Gamalama.
6. Aplikasi Penentuan Status Gunung Gamalama dengan Menggunkan Metode Case Based Reasoning berhasil dibuat dan berhasil diterapkan metodenya sesuai dengan yang telah direncanakan.

\section{DAFTAR PUSTAKA}

[1] T. R. I. Yogatama, "Risiko Bencana Letusan Gunung Gede di Kecamatan Cipinas," Universitas Indonesia, 2012.

[2] Firmansyah, "Identifikasi Tingkat Risiko Bencana Letusan Gunung Api Gamalama Di Kota Ternate," J. Lingkung. dan Bencana Geol., vol. 2, no. 3, pp. 203-219, 2011.

[3] A. Abdiansah, "Fuzzy Case-Based Reasoning: Implementasi Logika Fuzzy pada Case-Based Reasoning," J. Generic, vol. 8, no. 1, pp. 111, 2013.

[4] S. Hendra and S. Kusumadew, "Fungsi Similaritas Pada Sistem Berbasis Kasus Penyelesaian Masalah Akademik Mahasiswa," Semin. Nas. Inform. Medis, no. 3, pp. 116123, 2015.

[5] W. Oktinas, "Analisis Sentimen Pada Acara Televisi Menggunakan Improved K-Nearest Neighbor," 2017.

[6] I. W. Perdana, "Klasifikasi Jenis Gempa Gunung Berapi Menggunakan Jaringan Saraf Tiruan Backpropagation,” 2013.

[7] Tempola, F., Arief, A., dan Muhammad, M., 2017. Combination Of Case-Based Reasoning And Nearest Neighbour For Recommendation Of Volcano Status. ICITISEE 2017 (https://ieeexplore.ieee.org/document/8285525 / : dikases 20 Januari 2018) 